DOI: https://doi.org/10.33739/2587-5434-2019-20-26

\author{
Zoia Adamia \\ Doctor of Philology, Professor \\ D. Gulia Institute of History, Language and Culture \\ Tskhum-Abkhazian Academy of Sciences \\ (Tbilisi, Georgia) \\ e-mail: a.zoia777@gmail.com
}

\title{
COMPARATIVE ANALYSIS OF BIBLICAL PHRASEOLOGICAL UNITS (IN RUSSIAN, ENGLISH AND GEORGIAN LANGUAGES)
}

\begin{abstract}
Every culture is known to be distinctly defined by its language. Phraseological units are very effective modes of communication in everyday conversations, in political discourse, in the mass media, in literary works and in advertisements.

In this paper we have attempted to present phraseological units in three languages adapting bible words and expressions having certain pure linguistic features showing powerful universal and national culturological and language capacity.

The object of the work are words and expressions dating back to the Bible, and their equivalents in Russian, English and Georgian.

The paper describes the similarities and differences of the biblical phraseological units in three languages.

In conclusion, we will emphasize that the comparative analysis of Biblical phraseological units of various languages will be useful to compiling of the typological passport (Vladimir D. Arakin's idea (Arakin 1983: 1-35)) of phraseology of each concrete language.
\end{abstract}

Keywords: comparative analysis, biblical phraseological units, expressions, language, translation

\author{
Зоя Адамия \\ Доктор филолгии, профессор \\ Институт «Истории, языка и культуры» им. Д. Гулия \\ Цхум-Абхазская академия наук \\ (Тбилиси, Грузия) \\ e-mail: a.zoia777@gmail.com
}

\section{СРАВНИТЕЛЬНЫЙ АНАЛИЗ БИБЛЕЙСКИХ ФРАЗЕОЛОГИЗМОВ (В РУССКОМ, АНГЛИЙСКОМ И ГРУЗИНСКОМ ЯЗЫКАХ)}

Аннотация. Известно, что каждая культура четко определяется своим языком. Фразеологические единицы - очень эффективные способы общения в быту, в политическом дискурсе, в средствах массовой информации, в литературных произведениях и в рекламе.

В статье мы представили библейские слова и выражения на трех языках, имеющие чисто лингвистические особенности, демонстрирующие мощный универсальный и фактически национальный культурологический и языковой потенциал.

Объектом работы являются фразеологизмы, слова и выражения, относящиеся к Библии, и их эквиваленты на русском, английском и грузинском языках. 
В статье описаны сходства и различия библейских фразеологизмов в трех языках.

В заключение подчеркнем, что сравнительный анализ библейских фразеологизмов различных языков будет полезен для составления типологического паспорта (идея Владимира Д. Аракина (Аракин 1983: 1-35)) фразеологии каждого конкретного языка.

Ключевые слова: сравнительный анализ, библейские фразеологизмы, выражения, язык, перевод

\section{INTRODUCTION}

Language is known to be a means of communication between people and culture and a certain level of development of society. It is important to stress the point that "the Holy Bible is an exhaustible source of enduring phrases enriching the spoken language and the thought in general" (Fedulenkova 2018: 14).

Phraseological units are unique richness of lexicon of any language. They are not simply graceful expressions, emotions of thought, the history and events remaining in memory of people that are reflected in languages.

Phraseological units are speech units the contents, the capacity of thought and emotions of which have been isolated from "ordinary" lexicon and got independent art value.

We fully agree with V. Mokienko's opinion that, the language of the Bible has a huge impact on the formation of the literary languages of many peoples since ancient times acquainted with Christian culture. The translations of the Holy Writ into national languages became a basis of book languages of Europe, including Slavic. Thus, that commenting on the text of the Bible is one of the most ancient and most traditional occupations of the philologists, many aspects of this difficult perspective should be referred to the little developed. Questions of specifics of assimilation by concrete languages of those elements which go back to the Bible text, about nature of their further development in each of these languages, etc. are that in particular (Mokienko 2003: 144).

Lomakina O.V. demarcates biblical phraseological units from words and phrases from the Bible relating to texts of Holy Scripture, including toponyms (Babylon, Nazareth, etc.), anthroponyms (Noah, Cain, etc.) (Lomakina 2018: 24-25).

\section{REVIEW OF LITERATURE}

Interest in biblical phraseological units has recently greatly increased. Dictionaries began to grow. Biblical phraseological units are used in everyday life and in the media.

Many scientists are engaged in the study of biblical phraseological units in a comparative aspect, conferences are held, monographs are published (M. Silva, Mac Cormac Earl R. F., V. G. Gak, K. N. Dubrovina etc.), lectures on biblical phraseology (A. V. Kunin, T. N. Fedulenkova etc.) dictionaries and reference books (V. M. Mokienko, H. Walter, D. Balakova, G. Lilich etc.).

As for the English biblical phraseological units A. V. Kunin, there are "English-Russian phraseological dictionary" (407 biblical phraseological units were studied and described).

English linguist Logan P. Smith (studied and described 158 biblical phraseological units). 
As a special category of phraseological units for the first time, biblical phraseological units were singled out by English linguist Logan P. Smith in the twenties. Logan P. Smith only states the fact that there is a sufficiently large group of phraseological units in the language, going back to the Bible, and lists them. An English scientist lists 158 phraseological units of Biblical etymology, for example: the gift of tongues, Balm in Gilead, whited secure, a broken reed, and others (Fudulenkova 2018)

\section{RESEARCH METHODS}

Research methods in this work are: descriptive, comparative analysis method (R.R.K. Hartmann 1980: 69, 71), phraseological identification method (A.V. Kunin 1964: 9), comparative analysis of Biblical phraseological units of various languages will be useful to compiling of the typological passport (Vladimir D. Arakin's idea (Arakin 1983: 1-35)) of phraseology of each concrete language.

\section{RESULTS AND DISCUSSION}

The world of Slavic languages is huge as territorially and in the language relation. It is well reflected also in names of Slavic languages: West Slavic languages, Southern Slavic languages, East Slavic languages. They dispersed from each other many centuries ago, however, feeling of their relationship and unity by origin kept up to now. This unity is felt both in phonetics, and in morphology, and especially in lexicon. It doesn't mean that they simply repeat each other. In the course of centuries there were also distinctions, including in phraseological units, and as a whole in lexicon of Slavic languages.

If judging this problem on a current state of lexicon and phraseological units of Slavic languages, we will find two big layers of sources of phraseological units. First 'layer' is phraseological units which obviously 'smell' as paganism and second 'layer' is the phraseological units, originated by spread of Christianity in Slavic languages. This group of phraseological units is less original, than phraseological units of the first group. Let's give some examples both from the first, and from the second groups.

\section{I-group}

1. Phraseological units still having kept an echo of the paganisms: Он (кто-то) на этом деле собаку съел. (Approximately the English translation of this expression is the following: He has cut his teeth on (is very experienced in) this kind of tasks /business/). It is an echo of that time when it seemed to people that dog's food was the kind of food which enriched a person with magic knowledge.

2. В тихом болоте черти водятся (Here is the English version of this proverb: Still waters run deep). Why in the still waters (в тихом болоте)? Yes, because water is usually motionless in a bog. The fluid water is considered pure, and standing one is a whirlpool, quite often rotten water where unless only devils can exist.

3. Лиха беда начало (A good beginning makes a good ending). It means that the beginning is the most difficult stage in any business. In this expression the first lexical component is un- 
derstood now differently. The meaning of the word беда (trouble) is clear, but it is very difficult to understand the expression лиха беда (dashing trouble).

\section{II-group}

Examples from the second group, i.e. phraseological units connected with Christian dogma: Бога ради. Храни Вас Господь. Христа ради. Око за око зуб за зуб. Не судите, да не судимы будете. Люби ближнего своего, как самого себя.

(For God's sake. Keep you the Lord. For Goodness sake. An eye for an eye and a tooth for a tooth. Don't judge and won't be judged. Love the neighbor, as thyself, etc).

Biblical phraseological units entered Slavic languages after the translation of biblical books. The Christian religion forced out pagan polytheism and became the only source of a Christian's belief, moral and of life of behavior of the Christian. As is known in the XVII century in Russia the book 'Како жити христианам' was created. In this peculiar treatise of a moral is rather described in detail how the Christian man and woman should live and behave. One of necessary conditions is a woman's humility to man's will: Да убоится жена мужа своего.

The main distinction in sounding and understanding of biblical phraseological units in Slavic languages is a lexicon, but not significance i.e. over time the same Christian concepts have been designated differently by synonymous words, for example, that for Orthodox a молитва (a prayer), and for Catholics is месса (a mass). Hence, there is an ironical expression: Каждыци поет свою мессу.

With the spread of Christianity similar processes happened both in English, in Georgian, and other Christian languages. Let's give some examples from the Georgian language. Georgia has been in the sphere of world culture since ancient times. The Georgians are very ancient people with distinct national and cultural traditions. The Georgians church was one of the first of orthodox churches.

'According to Orthodox tradition, Christianity was first preached in Georgia by the Apostles Simon and Andrew in the 1st century.

It became the state religion of Kartli (Iberia) in 337'. (Toumanoff, Cyril, 1963:374-377), (Rapp, Stephen, 2007, 2012:138).

Georgian Orthodoxy has been a state religion in parts of Georgia since the 4th century and is the major religion in that country.

The new religion vigorously drove out old pagan religion and new phraseological units entered and were fixed in the people's life. In this regard one phraseological unit is interesting with what the Georgian national fairy tale usually begins. oym cos sms oym ms nzonob y3jombo ms offjömcos.

In the German variant of the Georgian fairy tales, this beginning is not translated. The translator Vera Novek explained it so: Georgians at the beginning of fairy tales instead of the Supreme deity

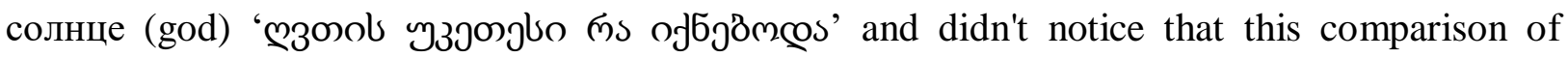
Christian god with something that contradicts understanding of God.

Examples from English, Russian and Georgian languages:

- You shell not murder (Exodus 20:13). 
Не убий (Исход 20:13).

sms zलms (zsambsoms 20:13).

- You shell not put The Lord your God to the test (Matthew 4:7).

Не искушай Господа Бога твоего (Исход 4:7).

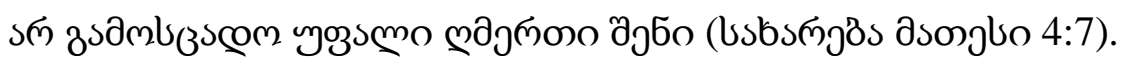

- You shell not misuse the name of the Lord your God (Exodus 20:7).

Не произноси имя Господа, Бога твоего, всуе (Исход 20:7).

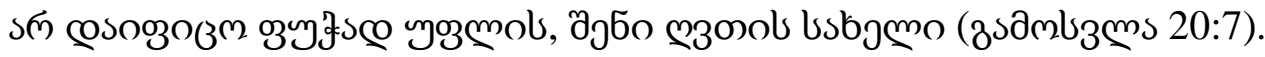

- You shell not commit adultery (Exodus 20:14).

Не прелюбодействуй (Исход 20:14).

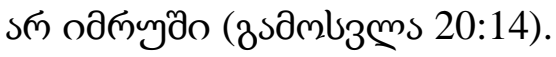

- Love your neighbor as yourself (Leviticus 19:18).

Люби ближнего своего как самого себя (Левит 19:18).

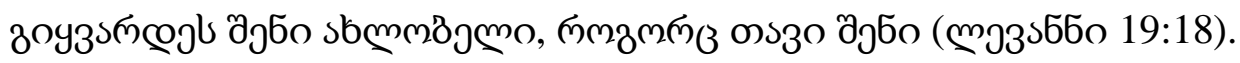

- The Lord gave, and the Lord has taken away (Job 1:21).

Господь дал, Господь и взял (Иов 1:21).

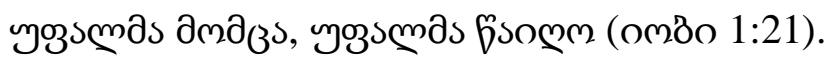

- Let those love the Lord hate evil (Psalm 96:10).

Любящие Господа, ненавидьте зло! (Псалом 96:10).

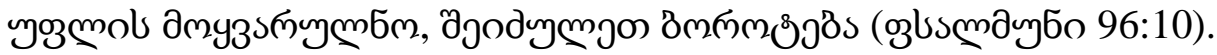

- You shall worship The Lord Your God, and serve him only (Matthew 4:10).

Господу богу твоему поклоняйся и Ему одному служи (от Матфея 4:10).

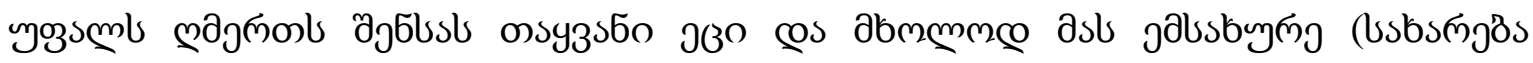
asonglo 4:10).

In English translation, we often come across the translation of the term Госnодь Бог/ The Lord your God. In language, the term was created which in due time was created for peoplelords. In Orthodoxy such a lexicon actually isn't present. In Orthodoxy, there was an ancient lexicon: in Russian Господь, in Georgian - ээзмп, мдэпоо. The word господин (in Russian), in

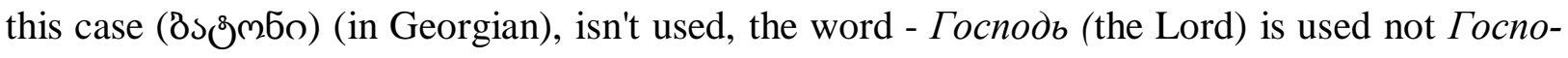
дин Бог, but Господь Бог.

\section{CONCLUSION}

The text of Bible is exclusively orthodox and canonized. That fact might have guaranteed a considerable monotony and similarity of its various translations into other languages. However, it is far not so. Russian and Georgian translations of Biblical phraseological units much more considerably coincide among themselves, than Georgian and English or Russian and English ones. It is apparently should be explained by the following:

1. The era of converting to Christianity by these or those people strongly influenced and character of translation, in particular, the lexicon and syntax of translation.

2. The Georgians and Russians keep to one tendency of Christianity, i.e. - Orthodoxy. It has been gone on for centuries. It has put its mark on their understanding of Christian dogmas, a role of religion in believers' everyday life. 
3. The European countries and peoples, converting of Christianity, relied on the knowledge in the field of classical philology, folklore, myths elements which are seen in biblical texts and many times have been specified throughout centuries. For those centuries, both translators' skills and consumers' tastes of translations have changed (Adamia 2016: 36 $37)$.

Every culture is distinctly defined by its language. Phraseological units are very effective modes of communication in everyday conversations, in political discourse, in the mass media, in literary works and in advertisements.

In the paper, we have attempted to present phraseological units in three languages adapting bible words and expressions having certain pure linguistic features showing powerful universal and actually national culturological and language capacity.

\section{REFERENCES}

Adamia Z. (2016) Lexical and Stylistic analysis of Russian, English, Georgian Biblical Phraseological Units. S3 "Cross-linguistic and Cross-cultural Approaches to Phraseology". ESSE BOOK OF ABSTRACTS Galway, 36-37

Arakin V.D. (1983) Structurnaya tipologia russkogo i nekotoryh germanskih yazykov (edinitsy sopostavitel'no-tipologicheskogo analiza yazykov): Dis. D-ra nauk v forme nauch. doklada [Structural Typology of Russian and Some Germanic Languages (Units of ComparativeTypological Analysis of Languages: Habilitation Doctoral Dissertation in the form of a scientific report]. Moscow: Moscow Lenin Teachers Training Institute.

Ayto J. (2010). Oxford Dictionary of English Idioms. 3rd ed. Oxford: Oxford University Press. Crystal D. (1977). The Cambridge Encyclopedia of Language. $2^{\text {nd }}$ Ed. Cambridge University Press.

Crystal D. (2010): the King James Bible and the English Language. 1st ed. Oxford: Oxford University Press, 2010.

Fedulenkova T.N. (2018) Lektsii po angliyskoy frazeologii bibleyskogo proishozdenia [Lectures on English Phraseology of Biblical Origin]. Moscow: Izdat. Dom Akademii Estestvoznania.

Gelashvili E. (1999). English for Students of History. (p. 43), Tbilisi.

Good News Bible (1992). American Bible Society, New York.

Oxford Advanced Learner's Dictionary. (2007) Oxford University Press.

Gamrekeli N. N., E.A. Mgaloblishvili E. A. (1966). Gruzinsko- Russkiy frazeologicheskiy slovar. Sabch'ota sakartvelo.

Hartman R. R. K. (1980). Contrastive Textology: Comparative Discourse Analysis in Applied Linguistics

Volume 5 of Studies in descriptive linguistics, ISSN 0171-6794

Holy Bible (2011): King James Version (KJV). London: Collins.

Kunin A.V. (1996). Phraseology Course of the modern English language. Vysshaya SHKOLA.

Lomakina O. V. (2018) Frazeologija v tekste: Funkcionirovanie i idiostil'. Moskva

Mac Cormac Earl R. (1976) Metaphor and myth in science and religion. Duke University Press, Durham.

Mokienko V. M. (2013). Bibleizmi v evropeiskoi frazeologii I paremiologii. Slavyanskaya frazeologiya $i$ Biblia Kollektivnya monografia, 144-153 (pp.114-149). University of Greifswald

Rapp, Stephen H., Jr (2007). "7 - Georgian Christianity". The Blackwell Companion to Eastern Christianity. John Wiley \& Sons. (p. 138). ISBN 978-1-4443-3361-9. Retrieved 11 May 2012. 
Ronald Ridout, Clifford Witting (1997). Explanatory Dictionary of English Proverbs. (p. 11), S. Petersburg.

Rockwood C. (2009). Brewer's Dictionary of Phrase and Fable. 18th ed. Edinburgh: Chambers Harrap Publishers.

Silva M. (1983) Biblical Words and their Meanings. Grand Rapids. Michigan, Academic Books. Toumanoff, Cyril. (1963). "Iberia between Chosroid and Bagratid Rule", in Studies in Christian Caucasian History, (pp. 374-377), Georgetown.

Information about the author: Zoia Adamia - PhD, prof., Research worker of $\mathrm{D}$. Gulia Institute of History, Language and Culture at Tskum-Abkhazian Academy of Sciences. Editor-inChef of Scientific Journal "WEST-EAST", Deputy Chairman of the Scientific Council of International Scientific-Pedagogical Organization of Philologists "WEST-EAST" (Georgia).

e-mail: a.zoia777@gmail.com

Сведения об авторе: Зоя Адамия - Доктор филологии, проф., Институт «Истории, языка и культуры» им. Д. Гулия Цхум-Абхазской академии наук. Главный редактор научного журнала «WEST-EAST». Зам. председателя международной научно-педагогической организации филологов «Запад-Восток» (Грузия).

e-mail: a.zoia777@gmail.com

Manuscript received: 11/25/2018

Accepted for publication: $01 / 25 / 2019$

Рукопись получена: $11 / 25 / 2018$

Принята к печати: 01/25/2019 